\title{
BURNOUT PROFILE OF ELEMENTARY SCHOOL TEACHER EDUCATION STUDENTS (ESTES): FACTORS AND IMPLICATION OF GUIDANCE AND COUNSELING SERVICES
}

\author{
Mubiar Agustin ${ }^{1}$, Ruli Setiyadi ${ }^{2}$, Ryan Dwi Puspita ${ }^{3}$ \\ ${ }^{1}$ Universitas Pendidikan Indonesia \\ ${ }^{2}$ IKIP Siliwangi \\ ${ }^{3}$ IKIP Siliwangi \\ ${ }^{1}$ mubiar@upi.edu, ${ }^{2}$ setiyadiruli@ikipsiliwangi.ac.id, ${ }^{3}$ dwiryan531@ gmail.com
}

\begin{abstract}
This study departs from the discovery of the phenomenon of the burnout of learning experience of students, especially those who are already in the fourth or fifth semester of lecture activities. Symptoms of burnout experienced by students are in four areas, namely physical, emotional, intellectual, and low motivation. This study aims to find the profile of students' learning burnout, the underlying factors and their implications for guidance services. The method in this study uses a quantitative approach with descriptive analytic. The sample in this study was 53 randomly assigned ESTES. The instrument used in this study was a questionnaire to capture data about the learning burnout profile and also the underlying factors. The results showed that $60.38 \%$ of students experienced high levels of learning burnout and the rest were low. Based on the analysis, the factors that cause students' learning burnout as a result of the study show that the factors that are at a high rate are not able to accept if the grades are not in line with expectations and not confident to consult with lecturers about learning activities. The recommendations of this study are aimed at Academic Advisors, UPT LBK, Study Programs, and further researchers.
\end{abstract}

Keywords: Burnout, Elementary School Teacher Education Student (ESTES), Guidance and Counseling Services

\begin{abstract}
Abstrak
Penelitian ini berangkat dari ditemukannya fenomena kejenuhan belajar yang dialami oleh mahasiswa khususnya mereka yang sudah berada pada semester ke empat atau ke lima pada kegiatan perkuliahan. Gejala kejenuhan yang dialami oleh mahasiswa berada pada empat area yaitu kejenuhan fisik, emosional, intelektual, dan rendahnya motivasi. Penelitian ini bertujuan untuk menemukan profil kejenuhan belajar mahasiswa, faktor yang melatarbelakangi serta implikasinya terhadap layanan bimbingan. Metode dalam penelitian ini menggunakan pendekatan kuantitatif dengan deksriptif analitik. Sampel dalam penelitian ini adalah 53 orang mahasiswa Pendidikan Guru Sekolah Dasar yang ditentukan secara acak. Instrumen yang digunakan dalam penelitian ini adalah angket untuk menjaring data tentang profil kejenuhan belajar dan juga faktor-faktor yang melatarbelakanginya. Hasil penelitian menunjukkan bahwa 60,38 \% mahasiswa mengalami kejenuhan belajar yang dengan kategori tinggi dan sisanya rendah. Berdasarkan analisis, faktor penyebab kejenuhan belajar mahasiswa hasil penelitian menunjukkan faktor-faktor yang berada pada angka tinggi adalah tidak dapat menerima apabila nilai kuliah tidak sesuai dengan harapan dan tidak percaya diri untuk berkonsultasi kepada dosen. Rekomendasi penelitian ini ditujukan untuk Dosen Pembimbing Akademik, UPT LBK, Program Studi dan juga peneliti selanjutnya.
\end{abstract}

Kata Kunci: Kejenuhan Belajar, Mahasiswa Pendidikan Guru Sekolah Dasar, Layanan Bimbingan dan Konseling

\section{INTRODUCTION}

The main objectives of students entering college, in general, are to get job certainty, develop interests and talents and make friends. These indicators are in line with the results of 
research conducted by Goldsen in the United States which shows that $35 \%$ of students come to tertiary institutions with the main objective of learning science, $36 \%$ emphasize the development of skills and techniques relevant to future careers and $17 \%$ to get along with other friends (Supriadi, 2001).

Based on the objectives of students studying at tertiary institutions, it appears that most students have high expectations of the tertiary institutions they enter. At least this condition reflects that students enter Higher Education, in addition to obtaining a brighter and promising future they are also expected to have special advantages as a support to be able to compete and have high bargaining power in the work they will pursue in the future. This is in line with the opinion of Semiawan, S.C (1999) which states that the new civilization promised by the new 21 st century demands the ability of tertiary education graduates to perform so that they can survive (survive) and develop to achieve the actualization of excellence abilities optimally. In line with this opinion, further, Alwasilah (2007) states that quality learning activities in Higher Education should be based on the development of interactions that lead to the development of humanity between individuals (lecturers and students), so as to produce graduates who have the ability to compete in life events real.

Not all students' ideals are so high that they can be achieved, especially if the learning system that occurs in higher education tends to be monotonous. On the other hand, students become a cliche, because in general lecture material must be memorized; independence development rarely occurs based on creative activities in the context of explorative types of students. Another characteristic of conditions that often occur in classrooms is related to the transmission of knowledge that is "transferring" knowledge that does not give birth to preconditions to develop interest, concentration or readiness to learn (Skovholt, 2003, Dalton, 2003). The definition of burnout or burnout in psychological research can be interpreted as an affective state consisting of unpleasant feelings, lack of stimulation, and low physiological arousal (Pekrun et al., 2010).

Research on burnout has been conducted by experts including Daschmann, Goetz, Stupnisky (2014) exploring the antecedents of burnout, Eren \& Coskun (2016) the relationship between the level of burnout and student learning outcomes, Sharp (2017) characteristics, contributions and consequences of student burnout, Cul, Yao, Zang (2017) The effect of enthusiastic teachers in class who are tired of learning, Fatmawati (2018) the relationship between burnout and academic stress, Bella \& Ratna (2018) lazy behavior of students, Tam et.al. (2019) implications of teacher learning burnout, student burnout and motivation. 
The results of the research of some of the experts above are in line with the results of the researchers' initial interviews with students who consulted on academic matters, most students who had reached the fifth semester and above generally complained that they experienced burnout and fatigue in learning. Some of the factors that trigger this learning burnout include the learning conditions that are dominated by lecturers as a learning center (teacher center), the condition of a learning space that does not change from the side of the seat, paint the room and learning media, the tasks given by the lecturer are partly Great forces them to always think logically and systematically, according to students the overly frequent interaction with classmates informal contexts also influences the learning climate, and what makes them more saturated is the learning method which still applies a single learning method namely lecture or discussion. Student assessment of the quality of learning activities in most subjects is still considered to be lacking (quality), both in terms of the method, material, and way of teaching lecturers.

The number of activities and activities in the classroom, as well as the demands that must be experienced by students, can cause students to feel fatigued in all parts of the senses, and lack of enthusiasm in participating in teaching and learning activities arises burnout, less motivated, less attentive, no interest, and no results. From the symptoms that have been mentioned above shows students are experiencing burnout learning. From the explanation above, learning burnout is defined as a person's mental condition when experiencing a feeling of burnout and fatigue which is very severe, resulting in the emergence of feeling reluctant, lethargic, not eager to do learning activities (Khusumawati, 2014; Fatmawati 2018).

The conditions that occurred as in the above explanation triggered the emergence of the burnout of learning in college students which were marked by four main symptoms namely physical fatigue, psychological fatigue, intellectual fatigue, and low motivation. Obviously, the burnout of learning along with the underlying factors cannot be tolerated. Efforts are needed to help overcome them. Because learning burnout triggers the occurrence of stress and failure of academic focus and burnout also affects the poor inter and intrapersonal communication of students. The estuary can be a student experiencing academic failure and it can have an impact on other variables in the lives of students themselves. One effort to overcome this is to provide guidance and counseling services with a primary focus on academic and personal social guidance services for students.

This tutoring is intended so that students can achieve maximum learning achievement in accordance with their interests and talents. Some experts have examined the linkages of 
burnout with guidance and counseling including Dami \& Styorini (2016) the relationship of tutoring services with learning motivation, Mailita, Basyir, Abd (2016) counseling guidance teacher efforts in dealing with student learning burnout. In dealing with the problem of ESTES burnout, it is very necessary for the role of guidance and counseling services to help students to be optimal in the learning process.

Based on the study above, the study of this article focuses on the ESTES's burnout profile at the Indonesian Education University, learning burnout factors and implications on guidance and counseling.

\section{METHOD}

This research was conducted using a quantitative approach with analytic descriptive methods, which describe comprehensively the profile of students' learning burnout and their areas, as well as the factors triggering learning burnout and then analyze it using relevant theoretical studies and references. The sample in this study was 53 fifth semester ESTES randomly selected. The instrument used to measure the profile of student learning burnout as well as the contributing factor is the questionnaire that has been tested for validity and reliability. Data analysis was performed by mapping the areas of learning burnout based on four areas, namely intellectual, emotional, physical and motivational, and then analyzed their tendencies based on saturated and unsaturated categories. The factors that cause learning burnout are analyzed based on the number of responses on the items causing factors of learning burnout. Items with a process of more than 50 percent were included in the high category and displayed in the research findings.

\section{RESULTS}

The results of the research conducted showed that PGSD students who experienced burnout are as follows.

Table 1. Student Burnout Area Profile

\begin{tabular}{cccc}
\hline No & Indicator & \multicolumn{2}{c}{ Percentage } \\
\cline { 3 - 4 } & & High & Low \\
\hline 1 & Emotional Fatigue Area & $50.94 \%$ & $49.06 \%$ \\
2 & Areas of physical fatigue & $52.83 \%$ & $47.17 \%$ \\
3 & Cognitive fatigue Areas & $58.49 \%$ & $41.51 \%$ \\
4 & Motivation Loss Area & $58.49 \%$ & $41.51 \%$ \\
\hline
\end{tabular}

The results showed that the burnout of ESTES was $22.64 \%$ influenced by factors characteristic of students, $43.40 \%$ influenced by learning environment factors and $27.00 \%$ influenced by factors of emotional involvement with the learning environment. 
A more detailed description of the factors causing the learning burnout of ESTES is as follows:

Table 2. Indicator of Student Characteristics

\begin{tabular}{llr}
\hline No & \multicolumn{1}{c}{ Factors causing the learning burnout of ESTES } & Percentage \\
\hline 1 & Cannot be accepted if the lecture work is done is considered to be imperfect & $37.74 \%$ \\
2 & Cannot be accepted if the value of lectures does not meet expectations & $50.94 \%$ \\
3 & Never proud of the learning achievements achieved so far & $18.87 \%$ \\
4 & Not able to excel in learning & $11.32 \%$ \\
5 & Not have advantages in the academic field & $24.53 \%$ \\
6 & Offended by friends who provide input, ideas in learning activities & $1.89 \%$ \\
7 & Not confident to consult with lecturers about learning activities & $67.92 \%$ \\
8 & No the desire to work on college assignments as well as possible & $3.77 \%$ \\
9 & No encouragement to get a good academic value & $5.66 \%$ \\
10 & Using references for improvised college assignments & $37.74 \%$ \\
\hline
\end{tabular}

The learning environment indicators can be seen in the table below.

Table 3. Indicators of Learning Environment

\begin{tabular}{|c|c|c|}
\hline No & Indicators of Learning Environment & Percentage \\
\hline 1 & Felt the lighting of the study room is not good & $24.53 \%$ \\
\hline 2 & $\begin{array}{l}\text { Friends on campus do not want to be invited to a discussion of the } \\
\text { assignments of lectures }\end{array}$ & $7.55 \%$ \\
\hline 3 & Difficulty finding a lecturer to consult & $83.02 \%$ \\
\hline 4 & Personal problem with a lecturer & $1.89 \%$ \\
\hline 5 & An academic problem with a lecturer & $0 c$ \\
\hline 6 & Ideas in learning that many have not heard from friends & $11.32 \%$ \\
\hline 7 & Learning methods delivered by the lecturer So far, it tends & $62.26^{c}$ \\
\hline 8 & Difficulty in finding references to complete college assignments & 77.36 \\
\hline 9 & Assignments given by lecturers are too abstract & 39.62 \\
\hline 10 & Difficulty in translating foreign literature & 98.11 \\
\hline 11 & Given by lecturers so far are subjective and tend to be discriminatory & 26.42 \\
\hline 12 & Statements Aya to do the work & 88.68 \\
\hline
\end{tabular}

The last indicator is indicators of emotional involvement with the learning environment, explanation is in the table below.

Table 4. Indicators of Emotional Involvement with the Learning Environment

\begin{tabular}{llr}
\hline No & \multicolumn{1}{c}{$\begin{array}{c}\text { Indicators of Emotional Involvement with the Learning } \\
\text { Environment }\end{array}$} & Percentage \\
\hline 1 & Being unable to reject a friend's invitation while studying & $26.42 \%$ \\
2 & Happy to end the time to work on college assignments & $58.49 \%$ \\
3 & Concerned with the desires of others rather than their own interests & $22.64 \%$ \\
& included in learning & \\
4 & Problems in families that interfere with learning activities & $18.87 \%$ \\
5 & Financial shortage for living and learning costs & 47.17 \\
6 & Difficulty dividing study time with busyness outside of learning & $54.72 \%$ \\
7 & Parents never asked for progress and learning problems & $28.30 \%$
\end{tabular}


8 Feeling forced by the desire of parents to enter the study program/majors currently undertaken

9 Activities outside of learning that has been undertaken has been most beneficial

10 The lecturer does not provide support for success in learning

11 Achievement achievement will not promise the future, which is better

\section{DISCUSSION}

The results showed that ESTES tended to experience high learning burnout and this high category also applies to all areas of learning burnout itself. Then when viewed from the point of view the biggest factors causing student burnout are indicators as follows. (1) can not accept if the value of the lecture does not meet expectations; (2) not confident to consult with lecturers about learning activities; (3) having difficulty meeting with lecturers to consult; (4) The learning methods conveyed by the lecturers so far tend to be mention; (5) difficulty in finding references to complete college assignments; (6) difficulties in translating foreign literature; (7) many costs to do the work; (8) happy ending the time to work on college assignments, and (9) Difficulty dividing learning time with activity outside of learning. The reality of student burnout along with the factors that influence it confirms that it could be that the learning climate in the higher education scene is not conducive, less accommodating and tends to tend towards intellectual development rather than the emotional and personality development of students themselves. In line with this fact, Pham (2007) states "When students don't feel appreciated or receive rewards for hard work, they can be frustrated and this feeling, in combination with other" mismatches "in everyday life, can escalate into burnout". Pham's statement indirectly illustrates that the burnout of learning in students occurs because of the many task pressures and lack of appreciation.

This means that the touch given by the instructor to students is apparently not enough to be of intellectual development only but an approach that is more psychological in touch with students also needs to be done especially in this period students begin to be demanded to be independent and responsible. It seems that the thoughts of Abrams et al. (2005) state that "Schools today are called upon to educate an increasing number of students with social and emotional needs that interfere with their academic success." Abrams's statement actually emphasizes that academic intake alone is not enough to make students successful but academic intake quality needs to be accompanied by quality emotional and social intake. It turns out that the appreciation and psychological touch is given to someone, whether physical, psychological, or social in nature can help to improve the mental health of individuals including students (Yusuf, 
2004). The results of this study mean that students who experience academic procrastination on some symptoms are the same as students who experience burnout in learning. Liwze (2002) states that: Student burnout is on the rise like academic procrastination. Two in ten Canadian students will experience burnout during their tenure at university according to a 2002 Canada Health survey that suggests students are feeling pressured to perform at work, at school and socially. The above opinion confirms that the risk of academic disruption in the form of burnout is as dangerous as academic procrastination. The Canadian Health Agency survey results show that two out of ten students experience psychological pressure both in school and social relationships. Related to efforts to help overcome the burnout of learning, it seems that Pennington (2007) can be considered by higher education institutions stating that although there is no sure cure or solution to make your classes perfect, there are some methods that may offer diversity for both of you and your students that will apply both to the academic classroom as well as the activity class. Pennington's statement implies the need to shift the learning method from active teachers towards active students as a solution to reduce the burnout of student learning. This means that the interaction of educators in tertiary institutions no longer only emphasizes the intellectual aspect, but psychological interaction with students also needs to be developed as an effort to help deal with student burnout because under stressful and stressful conditions it is not possible for a student to optimally develop his academic potential. Related to efforts to help overcome the burnout, the results of the study of Josepha et al. (1999) emphasized the need for non-academic student activities programs to strengthen the relationship between educators and students while helping to dilute previously frozen situations. The program discussed many things related to learning from self-management in learning to effective efforts to adapt to the environment in an effort to help deal with the burnout. This means that one of the efforts to overcome the burnout of student needs guidance and counseling services, especially academic services and social personal services.

\section{CONCLUSION}

The results showed that the majority of ESTES experienced high levels of learning burnout and the rest were low. The high level of learning burnout experienced by students applies to all areas, namely intellectual, emotional, physical exhaustion and also low motivation. In addition to the area of learning burnout, in terms of the factors that cause student burnout, the following factors are the main factors contributing to the burnout of learning in ESTES, namely (1) unable to accept if the course grades are not in line with expectations; (2) 
not confident to consult with lecturers about learning activities; (3) having difficulty meeting with lecturers to consult; (4) The learning methods conveyed by the lecturers so far tend to be monotonous; (5) difficulty in finding references to complete college assignments; (6) difficulties in translating foreign literature; (7) many costs to do the work; (8) happy ending the time to work on college assignments; and (9) Difficulty dividing learning time with activity outside of learning.

As a suggestion from the research results, it should be followed up immediately by designing an appropriate guidance and counseling service program to deal with students' burnout, especially through academic guidance services and also social personal services. There is also a need to balance the content of lecture material between theoretical and practical matters. It seems that for students who are already in semester 4 and above the content of lecture material the portion of material that is practical in nature needs to be strengthened with assignments that remain measurable and of good quality. And it is necessary to strengthen the relationship between lecturers and students who are more equal, communicative and mutually respectful while maintaining the norms and rules that apply.

\section{ACKNOWLEDGMENTS}

Our gratitude goes to all parties involved in this research. especially to IKIP Siliwangi's ESTES who gave their time in this study. then, our thanks go to the Primaryedu journal team who gave us the opportunity to be able to publish in their journals.

\section{REFERENCES}

Abrams, et al. (2005). Children and Adolescents who are Depressed: An Ecological Approach. Professional School Counseling, Feb 2005 [Online]. Tersedia: http://www.findarticles.com/p/articles. [7 February 2008].

Alwasilah, A. (2007). Quality Teaching at a Leading and Outstanding University: A Conceptual Framework for Action and Development. Bandung: UPI Press.

Bella, Mei Mita, Ratna, Luluk Widya. (2018). Perilaku Malas Belajar Mahasiswa di Lingkungan Kampus Universitas Trunojoyo Madura. Kompetensi. 12(2), 280-303.

Cui, Guanyu Cui1, Yao, Meilin, Zang, Xia. (2017). The Dampening Effects of Perceived Teacher Enthusiasm on Class-Related Burnout: The Mediating Role of Perceived Autonomy Support and Task Value. Frontiers in Psychology. 8, 1-11.

Dami, Zummy Anselmus, Styorini, Indah Novi. (2016). Hubungan Layanan Bimbingan Belajar dengan Motivasi Belajar. Jurnal Cakrawala. 5(11), 958-974. 
Daschmann, Elena C., Goetzl, Thomas, Stupnisky, Robert H.(2011). Testing the predictors of burnout at school: Development and validation of the precursors to burnout scales. British Journal of Educational Psychology. 81(3), 421-440.

Dalton. (2003). "Student Learning Burnout and Perceptions of a Democratic School Environment". International Education Journal. 4(2),

Eren, Altay, Coskun, Hamit. (2016). Students' level of burnout, burnout coping strategies, epistemic curiosity, and graded performance. The Journal of Educational Research. 109(6), 574-588.

Fatmawati. (2018). Hubungan antara Kejenuhan Belajar dengan Stres Akademik. Psikoborneo. 6(4), 704-712.

Joseph A.B (1999). "Pattern of physical therapist students burnout within an academic semester". Journal, Physical Therapy Education, Spring 1999 [Online].Tersedia:http://findarticles.com/p/articles/mi_qa3956/is_199904/ai_n883505 8/pg_9 [25 February 2009].

Khusumawati, Z.K. 2014. Penerapan Kombinasi Antara Teknik Relaksasi dan SelfInstructionuntuk Mengurangi Kejenuhan Belajar. Jurnal BKUNESA. 05(01), 110.

Liwsze, D. (2002). Student Burnout Rising. Balance in a Hectic World Not Easy for Over Stressed Students. Professional School Counseling, Feb 2005. [Online].Tersedia:http://www.findarticles.com/p/articles/mi_m0KOC/is_3_8/ai_n977 5245/pg_5 [7 February 2008].

Mailita, Basyir, M. Nazir, Abd, Dahliana. (2016). Upaya Guru Bimbingan Konseling dalam Menangani Kejenuhan Belajar Siswa di SMP Negeri Banda Aceh. Jurnal Ilmiah Mahasiswa Bimbingan dan Konseling. 1(2), 14-26.

Maslach, C \& Leiter, P.M. (1993). The Truth About Burnout. How Organizations Cause Personal Stress and What to Do About It. San Francisco: Jossey-Bass Publishers.

Muladi,Y. et al. (2001). "Evaluasi Pelaksanaan Proses Pembelajaran Bidang Studi di FPTK UPI”. Jurnal Penelitian Pendidikan. 1(35), 103-118.

Penington, E.J. (2007). Classroom Burnout. [Online]. Tersedia : media.collegepublisher.com [19 Agustus 2008].

Pekrun, R., Goetz, T., Daniels, L. M., Stupnisky, R. H., \& Perry, R. P. (2010). Burnout in achievement settings: exploring control value antecedents and performance outcomes of a neglected emotion. Journal of Educational Psychology, 102(3), 531-549.

Pham, J. (2007). Burnout Afflicts Students: the Life of a College Student. Articles [Online]. Tersedia : www.findarticles.com [6 Juni 2008].

Semiawan, R. C. (1999). Pendidikan Tinggi: Peningkatan Kemampuan Manusia Sepanjang Hayat Seoptimal Mungkin. Grasindo: Jakarta.

Sharp, John G., Hemmings, Brian, Kay, Russell, Murphy, Barbara, Elliott, Sam Elliott. (2017). Academic burnout among students in higher education: A mixed-methods exploration

46 | BURNOUT PROFILE OF ELEMENTARY SCHOOL TEACHER EDUCATION STUDENTS (ESTES): FACTORS AND IMPLICATION OF GUIDANCE AND COUNSELING SERVICES 
of characteristics, contributors, and consequences. Journal of Further and Higher Education. 41(5), 657-677.

Supriadi, D. (2001). Isu dan Agenda Pendidikan Tinggi di Indonesia. Remaja Rosdakarya : Bandung.

Skovholt. (2003). Student Learning Burnout Studied. Families in Society: The Journal of Contemporary Human Services. 1 Oct 2003.

Tam, Katy Y. Y., Poon, Cyanea Y.S., Hui, Victoria K.Y., Wong, Christy, Y.F., Kwong, Vivian W.Y., Yuen, Gigi W.C., Chan, Christian S. (2019). Burnout begets burnout: An experience sampling study on the impact of teacher burnout on student burnout and motivation. British Journal of Educational Psychology. Accepted 24 July 2019.

Wahyuni, Ervika Dewi Wahyuni. (2018). Faktor-Faktor Penyebab Tingkat Kejenuhan Belajar Pendidikan Agama Islam (PAI) pada Jurusan PGSD di Universitas Islam Balitar. Konstruktivisme. 10 (2), 154-162.

Yusuf LN., S. (2004). Psikologi Perkembangan Anak dan Remaja. Bandung: Remaja Rosdakarya. 